\title{
Chromosome Number and Microsporogenesis in Paspalum maritimum (Caespitosa Group; Gramineae)
}

\author{
Eleniza de Victor Adamowski ${ }^{1}$, Maria Suely Pagliarini ${ }^{1 *}$ and Luiz Alberto Rocha Batista ${ }^{2}$ \\ 1. Department of Cell Biology and Genetics, State University of Maringá, 87020-900 Maringá-Paraná, Brazil \\ 2.Cattle Research Center of the Southwest/Embrapa, 13560-970, São Carlos-São Paulo, Brazil
}

\begin{abstract}
Despite of economic importance of the genus Paspalum, little or no cytologic information is available for many species. This is the first report about chromosome number and meiotic behavior for P. maritimum. The three accessions collected in Amapá State (North Region of Brazil) were tetraploid $(2 n=4 x=40)$ with the chromosomes associating predominantly as bivalents. The low frequency of multivalents suggested that they were segmental allotetraploids. All accessions showed a low rate of meiotic irregularities, and as a consequence the pollen fertility was high. The results suggested that these accessions presented potential for use in a hybridization program.
\end{abstract}

Key words: Paspalum maritimum, Chromosome number, Meiotic behavior, Pollen fertility.

\section{INTRODUCTION}

The genus Paspalum is a member of the tribe Paniceae (Gramineae). It is a diverse genus comprising more than 400 species distributed in tropical and warm temperate areas worldwide, with a center of diversity in South America. Several species are economically important for forage, turf and ornamental purposes (Burson \& Bennett, 1971). The plants vary in habit from vigorous-caespitose, up to $3 \mathrm{~m}$ tall, to dwarfish, not exceeding $3 \mathrm{~cm}$ in height. They occupy a great diversity of habitats, from lowlands to high mountains, and from wetlands, ponds and rivers to regions with a marked dry season and periodical fire (Rua \& Gróttola, 1997).

The botanical composition of natural grassland communities in Brazil shows a high contribution of species of the genus Paspalum. A high proportion of livestock production is based on natural pastures containing species of this genus (Pozzobon \& Valls, 1997). Despite the enormous existing genetic variability, few experimentally tested forage options are available. In order to diversify the forage options for the country, several projects are currently underway in different regions. About 215 accessions of some species from different regions of Brazil are under evaluation in terms of agronomic and zootechnic aspects at the Centro de Pesquisa de Pecuária do Sudeste/Empresa Brasileira de Pesquisa Agropecuária (Batista et al., 1995). The studies are directed at the choice of accessions for intra- and interspecific crosses in order to increase genetic variability and to obtain new varietes. Considering that in this genus poliploidy is frequent and is correlated with apomixis, knowledge about chromosome number and meiotic behavior of the accessions is needed to identify and characterize potentially useful germplasm (Burson, 1985). The objectives of this investigation were to determine the chromosome number and evaluate the meiotic behavior of three accessions of $P$. maritimum, a species never before cytologically studied.

\footnotetext{
* Author for correspondence
} 


\section{MATERIAL AND METHODS}

The cytogenetic studies were carried out on accessions from the Paspalum collection of CPPSE/EMBRAPA, located in São Carlos, SP, where they are kept in pots. This germplasm bank contains accessions obtained from collections made in different regions in the country, especially the South. In this paper we describe the chromosome number and meiotic behavior for three accessions of $P$. maritimum from the Northern Region of Brazil (State of Amapá). The accessions and their origins are described in Table 1.

Inflorescences in the ideal stage for meiotic studies were collected and fixed in Carnoy for 24 $\mathrm{h}$ and then transferred to $70 \%$ alcohol and stored under refrigeration until use. Microsporocytes were prepared by squashing and stained with $1 \%$ propionic carmine. Chromosome number was determined in five plants per accession during diakinesis. The meiotic chromosome association was evaluated in at least 20 cells in diakinesis and the meiotic behavior up to this phase was evaluated in more than 2000 microsporocytes. Pollen stainability, an estimate of pollen viability, was determined using a 1\% acetocarmine solution. A minimum of 500 pollen grains were observed at random for each plant.

\section{RESULTS AND DISCUSSION}

Although cytogenetic studies on the genus Paspalum were started during 1930 (Burton, 1940), no more than 100 species have been evaluated. In Brazil, especially for species occurring in the southern region, some studies have been conducted to determine chromosome number and to evaluate meiotic behavior (Moraes-Fernandes et al., 1968, 1974; Quarín et al., 1996; Pozzobon \& Valls, 1997; Burson, 1997; Freitas et al., 1997; Takayama et al., 1998) but many species in the other regions of the country have never been evaluated.

The three accessions of $P$. maritimum from Amapá State were tetraploids $(2 n=4 x=40)$ with chromosomes associating predominantly as bivalents. Fig. 1a shows a diakinesis with 20 bivalents, but a low frequency of PMCs with uniand trivalents and tetravalents (Fig. 1b) was also observed in the three accessions. Table 1 shows the range and the average per cell of all types of chromosome association. The pairing relationship observed in these accessions was very interesting when compared with those found in other Brazilian accessions of some species of the same germplasm collection analyzed by Takayama et al. (1998). The P. maritimum accessions showed a higher frequency of bivalents than those analyzed by Freitas et al. (1997).

The basic chromosome number of the genus Paspalum is usually considered to be $\mathrm{x}=10$ and 6 with a majority of species having multiples of 10 (Burson, 1975). Most Paspalum species are polyploid, mainly tetraploid. Tetraploidy, however, may originate in two ways, i. e, by duplication of the genome itself or by interspecific hybridization. The presence of multivalent chromosome associations in diakinesis indicates autotetraploidy with two homologous genomes, whereas the absence or a small number of tetravalents suggests allopolyploidy. Based on the low frequency of quadrivalents in the tetraploid accessions analyzed here, we suggest that they are segmental allotetraploids, i. e, the genomes of each species are aparently partially homologous. Segmental allotetraploidy is very common among Paspalum species (Burson \& Bennett, 1970, 1971; Burson, 1975, 1997; Norrmann et al., 1989; Quarín et al., 1996).

As a consequence of the low frequency of multivalent chromosome association in these accessions, the meiotic behavior was slightly irregular (Table 2). Precocious chromosome segregation in metaphase I (Fig. 1c) and laggards in anaphase I, leading to micronucleus formation in telophase I (Fig. 1d) was the most commom abnormality observed in the first meiosis. The frequency of abnormal cells in metaphase I and anaphase I in accessions BRA-015041 and BRA015059 was higher than expected considering the pairing relationships. At diakinesis these accessions showed more bivalents and fewer univalents than accession BRA-015067. In accessions BRA-015041 and BRA-015059 the greater number of early ascending univalent chromosomes resulted from precocious chiasmata terminalization. In Paspalum, in general, the bivalents showed one or two terminal chiasmata. Chiasmata have been widely discussed in the literature as being responsible for the maintenance of bivalents so that perfect chromosome segregation may occur. In these accessions, however, many precocious chiasma 
terminalizations were observed in diakinesis (Fig.

1a). 


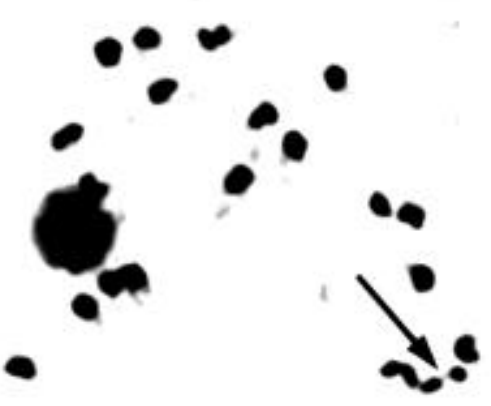

a
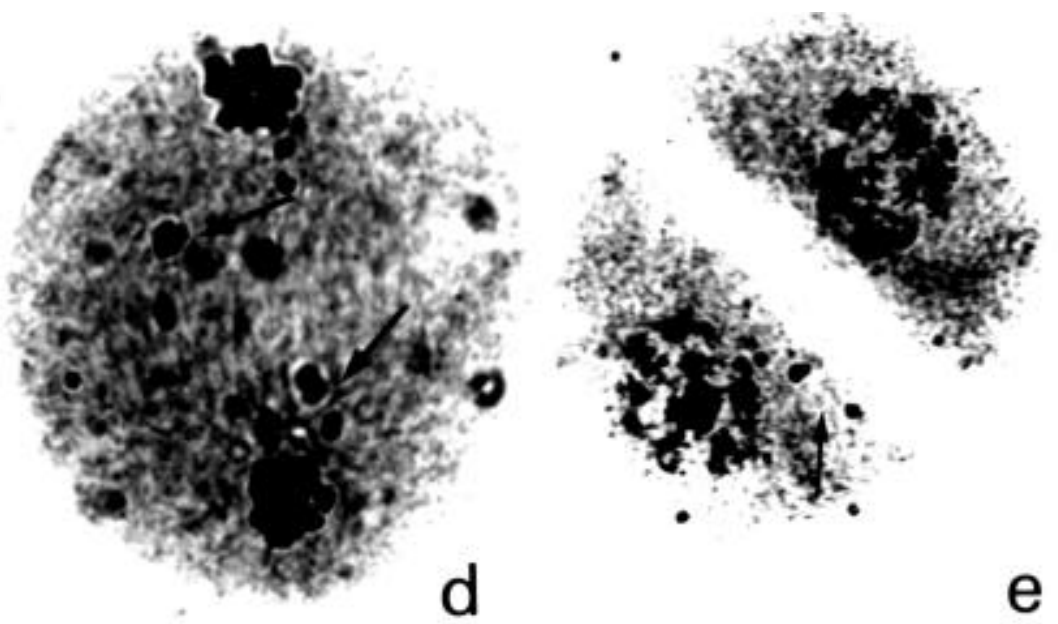

e
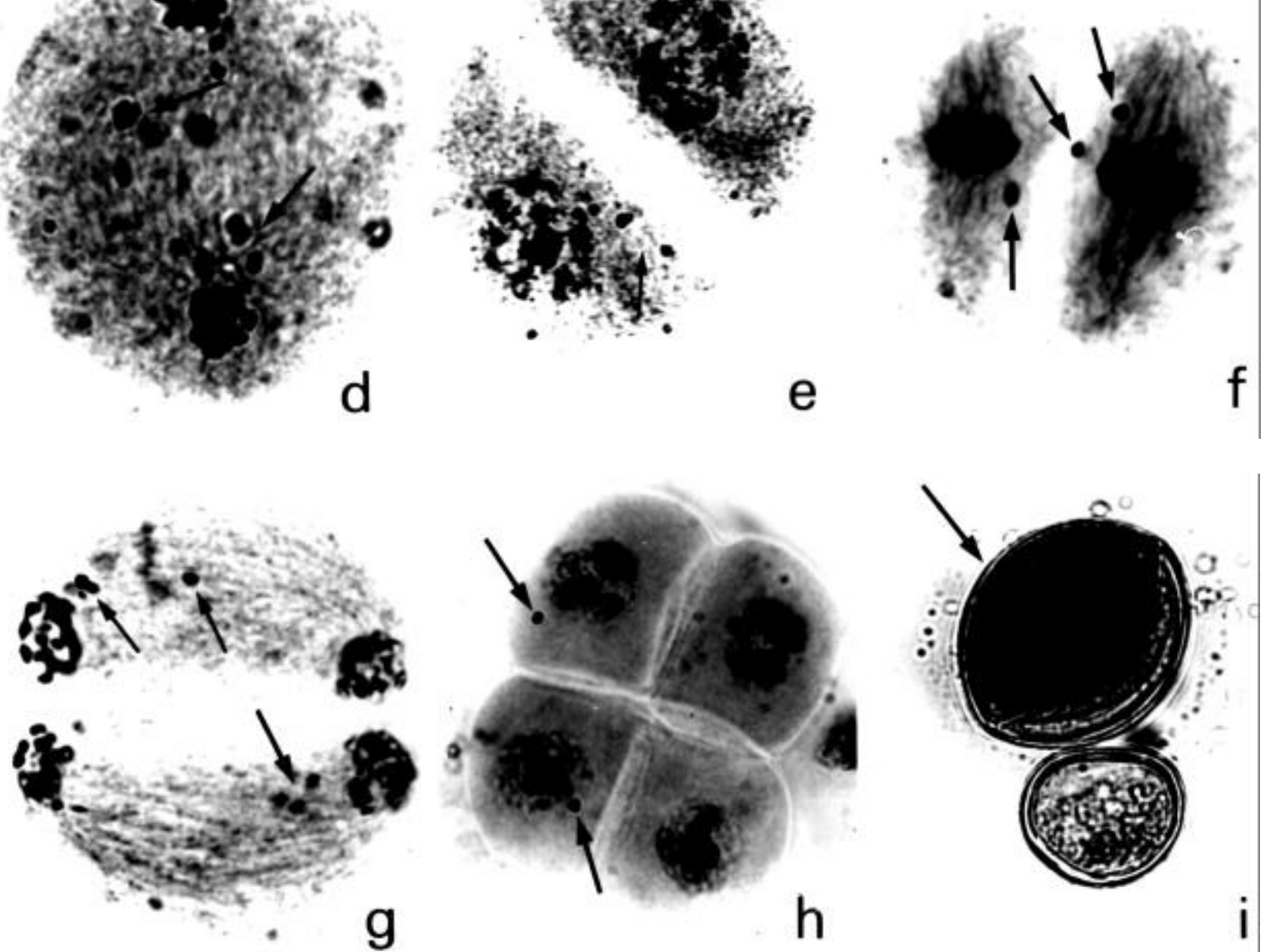

Figure 1. Aspects of meiotic behavior in P. maritimum. a) Diakinesis with 20 bivalents. The arrow shows precocious chiasma terminalization. b) diakinesis with 18 bivalents and one tetravalent (arrow). c) Metaphase I with univalent in precocious ascension (arrow). d) Telophase I with micronuclei (arrows). e) Prophase II with micronuclei (arrow). f) Metaphase II with micronuclei (arrows). g) Telophase II with micronuclei (arrows). h) Tetrad with two microspores with micronuclei (arrow). i) Fertile (arrow) and sterile pollen grains 
Table 1 - Chromosome number and meiotic chromosome association at diakinesis.

\begin{tabular}{|c|c|c|c|c|c|c|c|c|c|c|c|}
\hline \multirow{3}{*}{ Accession code } & \multirow{3}{*}{ Origin } & \multirow{3}{*}{$2 \mathrm{n}$} & \multirow{3}{*}{$\begin{array}{l}\text { No } \\
\text { PMCs }\end{array}$} & \multicolumn{8}{|c|}{ Chromosome association } \\
\hline & & & & \multicolumn{4}{|c|}{ Range } & \multicolumn{4}{|c|}{ Average per cell } \\
\hline & & & & I & II & III & IV & I & II & III & IV \\
\hline BRA-015041 & Macapá, AP & 40 & 20 & $(0-2)$ & $\begin{array}{l}(16- \\
20)\end{array}$ & $(0-1)$ & $(0-2)$ & 0.30 & 19.20 & 0.10 & 0.25 \\
\hline BRA-015059 & $\begin{array}{l}\text { Ferreira Gomes, } \\
\text { AP }\end{array}$ & 40 & 20 & $(0-2)$ & $\begin{array}{l}(16- \\
20)\end{array}$ & $(0-2)$ & $(0-2)$ & 0.55 & 18.40 & 0.15 & 0.55 \\
\hline BRA-015067 & Oiapoque, AP & 40 & 20 & $(0-4)$ & $\begin{array}{l}(15- \\
20)\end{array}$ & $(0-1)$ & $(0-2)$ & 0.75 & 19.05 & 0.05 & 0.25 \\
\hline
\end{tabular}

$\underline{\text { Table } 2 \text { - Percentage of cells with meiotic abnormalities }}$

\begin{tabular}{|c|c|c|c|c|c|c|c|c|c|c|c|}
\hline \multirow{2}{*}{$\begin{array}{l}\text { Accession } \\
\text { code }\end{array}$} & \multirow{2}{*}{$2 n$} & \multirow{2}{*}{$\begin{array}{c}\text { No } \\
\text { PMCs }\end{array}$} & \multicolumn{8}{|c|}{ Phases } & \multirow{2}{*}{$\begin{array}{l}\text { Pollen } \\
\text { fertility }\end{array}$} \\
\hline & & & Met.I & An. I & Tel. I & Pro. II & Met. II & An. II & Tel. II & Tetr. & \\
\hline BRA-015041 & 40 & 2026 & 19.20 & 18.23 & 11.35 & 17.09 & 20.47 & 4.34 & 9.24 & 6.23 & 93.54 \\
\hline BRA-015059 & 40 & 2034 & 11.15 & 13.00 & 3.21 & 4.41 & 5.79 & 2.98 & 5.22 & 6.56 & 89.18 \\
\hline BRA-015067 & 40 & 2357 & 16.15 & 8.94 & 4.71 & 4.80 & 11.14 & 2.31 & 4.93 & 5.72 & 92.75 \\
\hline
\end{tabular}

The percentage of abnormal cells in metaphase I and anaphase I was higher than that observed at telophase I, showing that the majority of univalents were included in the main nucleus. This seems to be the standard behavior for many species, as reported by Koduru \& Rao (1981). In the second division, there were fewer abnormal cells than in the first. In general, the micronuclei formed at telophase I remained until the tetrad stage (Fig. 1e, f, g, h). The more regular meiotic behavior and the highest frequency of normal tetrads distinguished the $P$. maritimum accessions from other tetraploids of the same germplasm collection previously evaluated by Freitas et al. (1997). As a consequence of a more regular meiosis, pollen fertility was high, ranging from $89.18 \%$ to $93.54 \%$ among accessions. This rate of pollen fertility is much more elevated than that found in other tetraploid Paspalum accessions (Burson \& Bennett, 1970; Burson, 1975, 1997; Quarín \& Burson, 1991).

Apomixis has been widely recognized as a common method of reproduction in the genus Paspalum (Quarín, 1986). In general, diploids were sexual and polyploids were apomictic. However, some polyploids reproduced sexually and many apomitics were facultative (Burson, 1997). Sexual reproduction in tetraploids has always been reported to occur in individuals with normal meiosis (Moraes-Fernandes et al., 1968; Burson \& Bennett, 1971; Quarín \& Norrmann,
1987). The conventional Paspalum breeding programs required sexual types for hybridization. Although the mode of reproduction was not determined in the present study, the low rate of meiotic abnormalities suggested that the accessions might be sexual. However, further studies are necessary to confirm this assumption. But if these studies do not corfim the presence of sexual reproduction, these accessions might be also used as pollen parents in interspecific hybridization programs, as proposed by Burson (1975) for other Paspalum species with considerable but lower pollen fertility than those observed in three accessions of $P$. maritimum.

\section{RESUMO}

Apesar da importância econômica do gênero Paspalum, pouca ou nenhuma informação citológica é encontrada para a maioria das espécies. Esta é a primeira descrição sobre número de cromossomos e comportamento meiótico para $P$. maritimum. Os três acessos coletados no Estado do Amapá mostraram-se tetraplóides $(2 n=4 x=40)$ com os cromossomos associando-se predominantemente como bivalentes. A baixa ocorrência de associações multivalentes sugere que estes acessos sejam 
alotetraplóides segmentais. Todos os acessos mostraram uma baixa frequência de anormalidades meióticas e, como consequência,

\section{REFERENCES}

Batista, L. A. R.; Godoy, R. E. \& Pereira, J. M. (1995), Potencial forrageiro de acessos de germoplasma de Paspalum. Ensaio 1993/94. In: XXXII Reunião Anual da Sociedade Brasileira de Zootecnia, Anais, Maringá-Paraná, pp 641.

Burson, B. L. (1997), Apomixis and sexuality in some Paspalum species. Crop Sci., 37, 1347-135.

Burson, B. L. \& Bennett, H. W. (1970), Cytology, method of reproduction and fertility of Brunswickgrass, Paspalum nicorae Parodi. Crop Sci., 10, 184-187.

Burson, B. L. \& Bennett, H. W. (1971), Chromosome number, microsporogenesis, and mode of reproduction of seven Paspalum species. Crop Sci., 11, 292-294.

Burton, G. W. (1940), A cytological study of some species in the genus Paspalum. J. Agric. Res., 60, 193-197.

Freitas, P. M.; Takayama, S. Y.; Pagliarini, M. S. \& Batista, L. A. R. (1997), Evaluation of meiotic behavior in polyploid accessions of Paspalum (Plicatula group). Nucleus, 40, 47-52.

Koduru, P. R. K. \& Rao, M. K. (1981), Cytogenetics of synaptic mutants in higher plants. Theor. Appl. Genet., 59, 197-214.

Moraes-Fernandes, M. I.; Barreto, I. L. \& Salzano, F. M. (1968), Cytogenetic, ecologic and morphologic studies in Brazilian forms of Paspalum dilatatum. Can. J. Genet. Cytol., 10, 131-138.

Moraes-Fernandes, M. I.; Barreto, I. L.; Salzano, F. M. \& Sacchet, A. M. O. F. (1974), Cytological and uma alta fertilidade de pólen, mostrando potencial para serem utilizados em programas de hibridização.

evolutionary relationships in Brazilian forms of Paspalum (Gramineae). Caryologia, 27, 455-465.

Norrmann, G. A.; Quarín, C. L. \& Burson, B. L. (1989), Cytogenetics and reproductive behavior of different chromosome races in six Paspalum species. $J$. Hered., 80, 24-28.

Pozzobon, M. T. \& Valls, J. F. M. (1997), Chromosome number in germoplasm accessions of Paspalum notatum (Gramineae). Braz. J. Genet., 20, 29-34.

Quarín, C. L. \& Norrmann, G. A. (1987), Cytology and reproductive behavior of Papalum equitans, $P$. ionanthum and their hybrids with diploid and tetraploid cytotypes of $P$. chromyorrhizon. Bot. Gaz., 148, 386-391.

Quarín, C. L.; Pozzobon, M. T. \& Valls, J. F. M. (1996), Cytology and reproductive behavior of diploid, tetraploid and hexaploid germplasm accessions of a wild forage grass: Paspalum compressifolium. Euphytica, 90, 345-349.

Rua, G. H. \& Gróttola, M. C. (1997), Growth form models within the genus Paspalum L. (Poaceae, Paniceae). Flora, 192, 65-80.

Takayama, S. Y.; Freitas, P. M.; Pagliarini, M. S. \& Batista, L. A. R. (1998), Chromosome number in germplasm accessions of Paspalum (Plicatula group) from different regions in Brazil. Euphytica, 99, 89-94.

Received: July 30, 1998; Revised: February 02, 1999; Accepted: February 15, 1999. 